\title{
Current situation and future prospects for the Australian beef industry - A review
}

\author{
Paul L Greenwood ${ }^{1,2, a, *}$, Graham E Gardner ${ }^{3, a}$, and Drewe M Ferguson ${ }^{2, a}$
}

* Corresponding Author: Paul L Greenwood Tel: +61-2-6776-1374, Fax: +61-2-6776-1333, E-mail: paul.greenwood@dpi.nsw.gov.au

${ }^{1}$ New South Wales Department of Primary Industries, Armidale Livestock Industries Centre, University of New England, Armidale NSW 2351, Australia 2 CSIRO Agriculture and Food, FD McMaster Laboratory Chiswick, Armidale NSW 2350, Australia

${ }^{3}$ Murdoch University, School of Veterinary and Life

Sciences, Murdoch WA 6150, Australia

a These authors contributed equally to this work.

ORCID

Paul L Greenwood

https://orcid.org/0000-0002-7719-8233

Graham E Gardner

https://orcid.org/0000-0001-7499-9986

Drewe M Ferguson

https://orcid.org/0000-0002-8805-0429

Submitted Jan 22, 2018; Revised Feb 25, 2018; Accepted Apr 2, 2018

\begin{abstract}
Beef production extends over almost half of Australia, with about 47,000 cattle producers that contribute about 20\% (\$A12.7 billion gross value of production) of the total value of farm production in Australia. Australia is one of the world's most efficient producers of cattle and was the world's third largest beef exporter in 2016. The Australian beef industry had 25 million head of cattle in 2016-17, with a national beef breeding herd of 11.5 million head. Australian beef production includes pasture-based cow-calf systems, a backgrounding or grow-out period on pasture, and feedlot or pasture finishing. Feedlot finishing has assumed more importance in recent years to assure the eating quality of beef entering the relatively small Australian domestic market, and to enhance the supply of higher value beef for export markets. Maintenance of Australia's preferred status as a quality assured supplier of high value beef produced under environmentally sustainable systems from 'disease-free' cattle is of highest importance. Stringent livestock and meat quality regulations and quality assurance systems, and productivity growth and efficiency across the supply chain to ensure price competiveness, are crucial for continued export market growth in the face of increasing competition. Major industry issues, that also represent research, development and adoption priorities and opportunities for the Australian beef industry have been captured within exhaustive strategic planning processes by the red meat and beef industries. At the broadest level, these issues include consumer and industry support, market growth and diversification, supply chain efficiency, productivity and profitability, environmental sustainability, and animal health and welfare. This review provides an overview of the Australian beef industry including current market trends and future prospects, and major issues and opportunities for the continued growth, development and profitability of the industry.
\end{abstract}

Keywords: Beef Markets; Beef Production; Beef Value Chain; Quality Assurance; Research and Development

\section{INTRODUCTION}

The Australian beef industry is a major contributor to the Australian economy. The gross value of cattle and beef production including live cattle exports was $\$ A 12.7$ billion with an off-farm value of $\$ A 16.9$ billion in 2016-17 [1]. Beef production represents about $20 \%$ of the total value of farm production in Australia.

The Australian beef industry had 25 million head of cattle, with a national beef breeding herd of 11.5 million head in 2016-17 [1]. Australian beef production includes pasture based cow-calf systems, a backgrounding or grow-out period on pasture, and feedlot or pasture finishing. The national herd covers a wide range of agro-climatic zones from northern tropical to southern Mediterranean or cool temperate systems, and comprises an equally wide range of tropically-adapted and temperate genotypes and their crosses within these systems. A national genetic improvement program, BREEDPLAN has existed since the mid-1980's 
and includes over 30 breeds, and a range of production, efficiency, carcass and beef quality traits used in Australia [2] and internationally [3].

The Australian domestic household market for beef demands a relatively lean product finished using pasture or shortfeedlotting. Higher value product is supplied into the domestic hospitality trade. Supply of Australian beef to export markets has increasingly been for higher-value product with emphasis on marbled beef to northern Asia following long-feedlotting, and more recently into emerging Asian markets including China and Indonesia, but also includes large volumes into the more traditional U.S. market [4].

Maintenance of Australia's preferred status as a quality assured supplier of high value beef produced under environmentally sustainable systems from 'disease-free' cattle is of high importance and is crucial for continued export market growth [5]. However, improvements in health status of cattle and traceability of beef by South American beef exporting nations, coupled with their lower production costs, have been reducing the gap between these countries and Australia as a preferred beef supplier [6]. Continued efforts to maintain advantages in provenance, coupled with productivity growth across the supply chain to ensure price competiveness, will be important for continued export market growth for Australian beef in the face of increasing competition.

This review provides an overview of the Australian beef

Top ten world beef exporters* (2016)

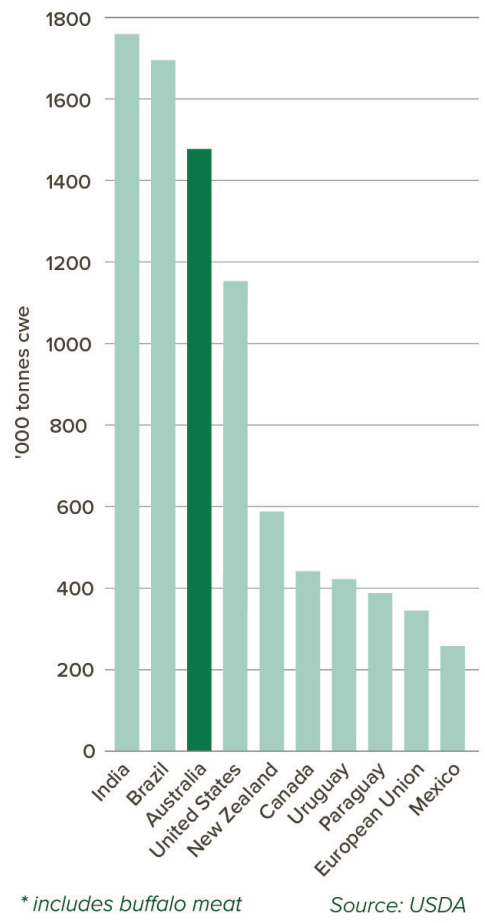

industry, current market trends and future prospects, megatrends that are likely to impact on the beef industry, and major issues and opportunities for the continued growth, development and profitability of the industry.

\section{AUSTRALIAN BEEF INDUSTRY OVERVIEW}

\section{Beef production and distribution of the beef industry across Australia}

A brief history and overview of the of the Australian beef industry is provided by [5,7]. Australia had about 25 million head of cattle, including 2.8 million head of dairy cattle, and 11.5 million beef cows and heifers in 2016-17 [1]. Australia has approximately $3 \%$ of the world cattle and buffalo inventory and with production of 2.07 million tonnes (carcass weight) in 2016-17, Australia produces just over 2\% of the world beef supply (Figure 1). The Australian beef industry is largely pasture- and rangeland-based. Australia is one of the world's most efficient producers of cattle and was the world's third largest exporter of beef in 2016 (Figure 1).

Beef production extends over almost half of Australia, with about 47,000 cattle producers or $55 \%$ of businesses within agricultural production [1]. Of these, over 10,000 are in northern Australia where beef cattle businesses are generally larger compared to those in southern Australia. The Australian red meat

Top ten beef producing countries* (2016)

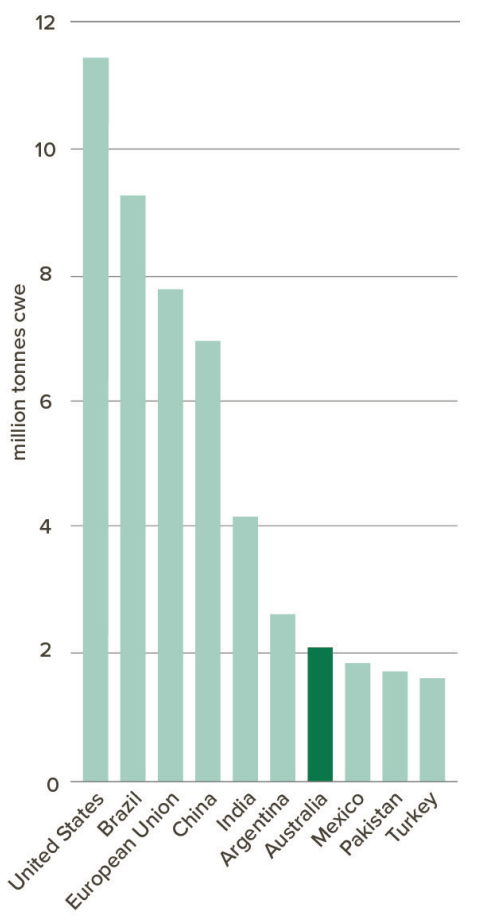

Figure 1. The world's largest beef producing and exporting countries in 2016 [1]. 


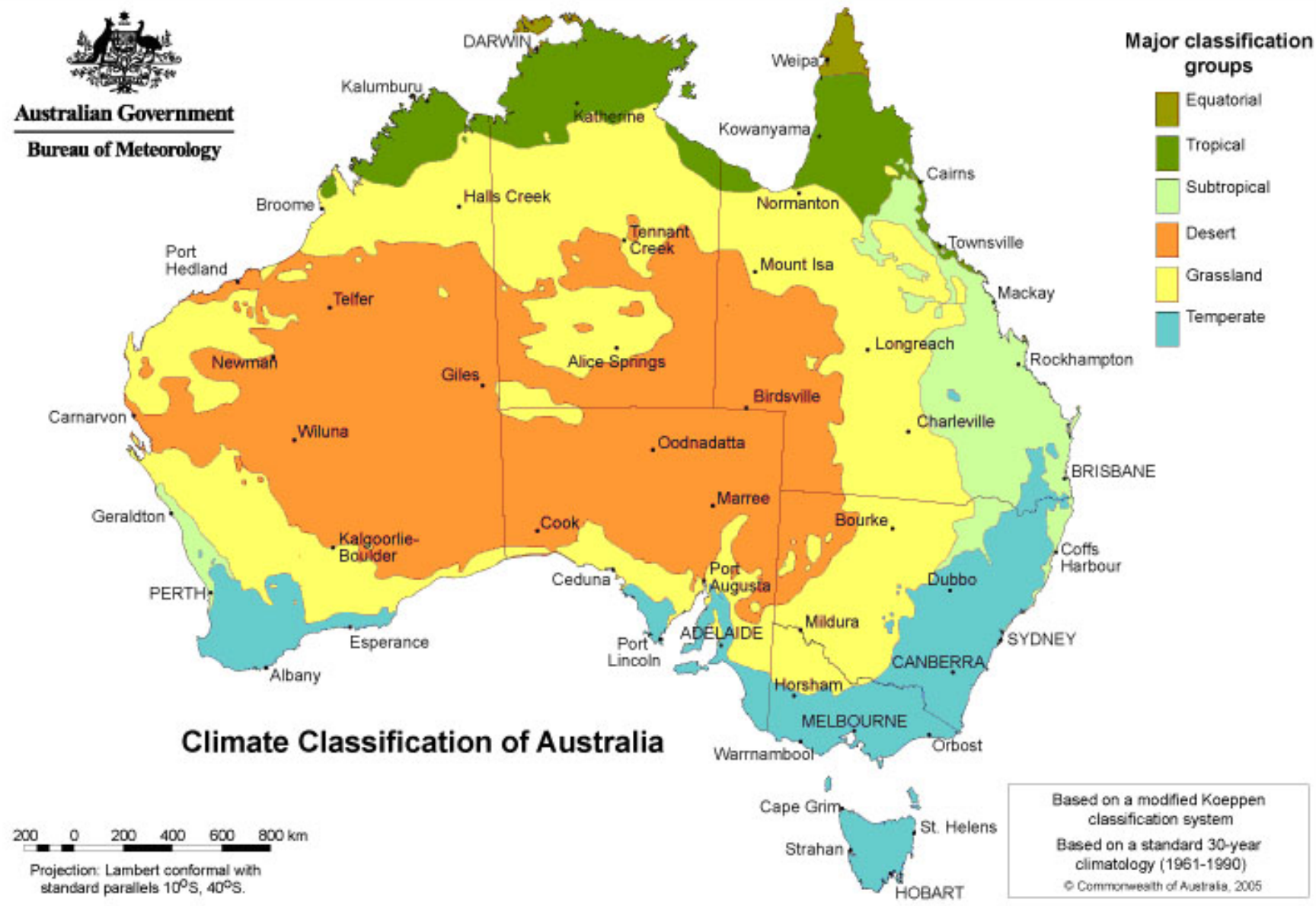

Figure 2. Climate classification in Australia [8].

industry employs about 200,000 people across the value chain.

Beef production in Australia is spread over all agro-climatic zones, from tropical savanna and forest in the north to cool- temperate Mediterranean and alpine in the South (Figure 2). Approximately $60 \%$ of Australia's cattle are in the northern areas of Australia (Figure 3), and the amount and value of beef

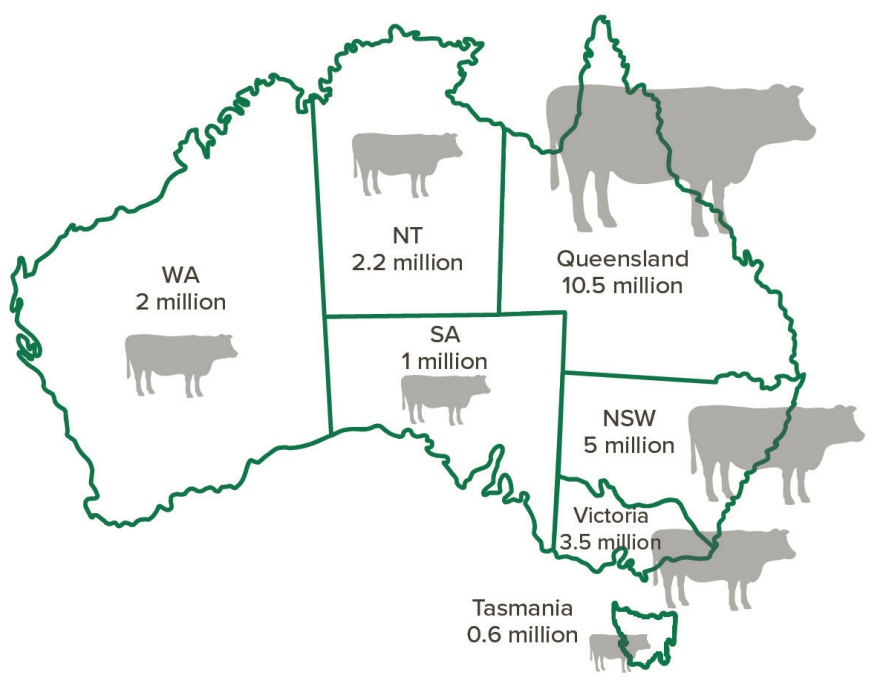

Source: ABS (final estimates 2016)

Figure 3. Distribution of Australia's 25 million cattle as at June 2016 [1]. 
produced is split about evenly between the north and the south of Australia, due to higher yields and also higher value markets traditionally supplied by temperate beef production systems. Feedlot finishing has assumed more importance in recent years to assure the eating quality of beef entering the domestic market and to enhance the supply of marbled beef for high value export markets including Japan and Korea.

\section{Structure of the Australian beef industry}

Supply chains: An overview of supply (value) chains for Australian beef is shown in Figure 4 [9]. Beef processors supply Australian domestic retail markets directly or via a wholesaler or broker, and supply export markets through importers in the destination country. The domestic retail market includes the food service industry, independent butcher shops and major supermarket chains. Slaughter cattle are sold to abattoirs predominantly by direct consignment but can also be procured via sale yards and electronic auction. Cattle destined for slaughter or live export are backgrounded after weaning and are then either finished in feedlots or on pasture. Cattle exported live for slaughter are generally backgrounded and may be fattened at pasture or in feedlot prior to export. Commercial cow-calf herds supply cattle for backgrounding, and obtain improved genetics from stud breeding herds.

Biosecurity and quality assurance: Australia lacks many ex- otic diseases present in other countries that are a risk to human health, cause major production losses and/or prevent international market access. Australia is free of foot and mouth disease (FMD), has had no recorded cases of bovine spongiform encephalopathy (BSE), and the successful implementation of the Brucellosis and Tuberculosis Eradication Campaign (BTEC) that commenced in 1970s resulted in Australia being brucellosis free by 1989 and declared free of tuberculosis in 1997 [10-12].

Australia has stringent, coordinated, nation-wide animal health prevention and control measures that include the national Emergency Animal Disease Response Agreement and the Australian Veterinary Emergency Plan, the management of which lies with Animal Health Australia (AHA) [10].

A National Livestock Identification System (NLIS) for cattle was introduced in 1999 to enhance Australia's ability to trace cattle during disease and food incidents [13]. The NLIS reflects Australia's commitment to biosecurity and food safety and provides a competitive advantage in the global market. The NLIS requires all Australian cattle to have an electronic identification ear tag from an early age and underpins the 'disease free,' 'clean and green' image of the Australian beef industry. The NLIS also provides a mechanism for other market-specification related information on individual cattle and their products to be translated across the supply chain and, ultimately,

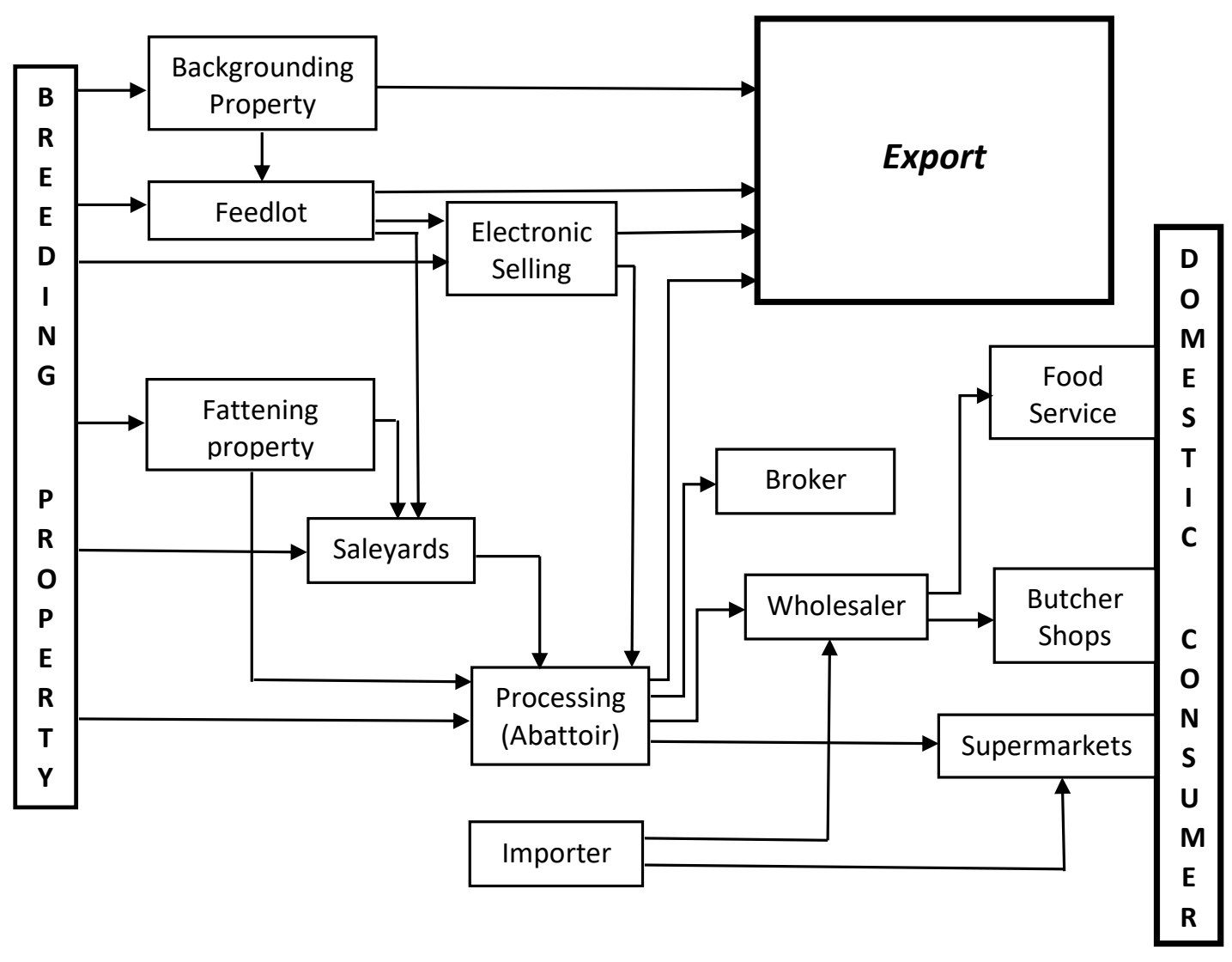

Figure 4. Schematic of Australian beef supply chains [9]. 
back to beef producers.

The Export Meat Program provides inspection, verification and certification services to the export meat industry in Australia [14]. The Meat Establishment Verification System provides a national approach to Federal Department of Agriculture and Water Resources (DAWR) inspection and verification of export registered abattoirs to support Australian Government health certification for export meat and meat products. The DAWR also regulates the live export industry [14]. Livestock exporters must meet high animal welfare standards through regulations such as those that underpin the Exporter Supply Chain Assurance System.

AUS-MEAT is responsible under Australian government regulations for the management of industry standards for trade description through the Australian Meat Industry Classification System (AUS-MEAT Language) and the AUS-MEAT National Accreditation Standards for AUS-MEAT Accredited Enterprises operating under internationally recognized ISO9001 Quality Management Systems [15]. The AUS-MEAT company is wholly owned by its member bodies, Meat \& Livestock Australia (MLA) and Australian Meat Processors Corporation.

Australian beef brands can choose to underpin the eating quality of their products by using Meat Standards Australia (MSA) standards and grading specifications $[16,17]$. These brands may also include additional specifications that can be applied at grading. The MSA symbol, established in Australia, is now used globally. MSA graded beef has met strict criteria developed using eating quality science supported by consumer taste panels. A comparison of international beef grading systems which demonstrates the range of inputs into the MSA beef grading system relative to other international systems is presented in Table 1.

Production systems: Australian beef production includes pasture- and rangeland-based cow-calf systems, a backgrounding or grow-out period on pasture, and feedlot or pasture/ forage finishing $[7,18]$. Southern Australian systems are generally more winter rainfall-dominant, and include New South Wales, Victoria, Tasmania, South Australia, and more southern parts of Western Australia. Northern Australian production systems are generally more extensive on larger properties particularly in more inland, rangeland-based production systems. Northern systems include Queensland, northern Western Australia and the Northern Territory. They are more summer rainfall-dominant with increasingly distinct wet and dry seasons further north that can result in water inundation and severe feed restrictions, respectively. In general, soils in Australia are of poor structure, prone to erosion and have low fertility, particularly in phosphorus and nitrogen which limits pasture production and livestock performance if not redressed.

Southern Australian beef enters export and domestic markets in roughly equal volumes. Northern production systems mainly supply cattle and beef export markets $[7,18]$. Within the northern beef industry, Western Australia and the more northern parts of the Northern Territory and Queensland mainly supply live cattle for export, and more southern parts of Queensland and the Northern Territory mainly produce

Table 1. Comparison of international beef eating quality grading systems [16]

\begin{tabular}{|c|c|c|c|c|}
\hline Grading inputs & $\begin{array}{c}\text { MSA } \\
\text { Meat Standards Australia }\end{array}$ & $\begin{array}{c}\text { USDA } \\
\text { United States } \\
\text { Department of Agriculture }\end{array}$ & $\begin{array}{c}\text { EUROP } \\
\text { European Beef } \\
\text { Grading Scheme }\end{array}$ & $\begin{array}{c}\text { JMGA } \\
\text { Japan Meat } \\
\text { Grading Association }\end{array}$ \\
\hline Tropical breed content & V & & & \\
\hline Hormonal growth promotant & V & & & \\
\hline Sex & V & & & \\
\hline Carcass weight & V & V & V & V \\
\hline Carcass conformation & & $\vee$ & V & \\
\hline Ossification (maturity) & $\vee$ & V & & \\
\hline Meat texture & & V & & $\vee$ \\
\hline Meat firmness & & $\vee$ & & $\vee$ \\
\hline Milk-fed veal & V & & & \\
\hline Carcass hanging method & $\vee$ & & & \\
\hline Marbling & V & V & & V \\
\hline Meat colour & $\vee$ & $\vee$ & & V \\
\hline $\mathrm{pH}$ & V & & & \\
\hline Rib fat measurement & V & $\vee$ & $\vee$ & $\vee$ \\
\hline Ribeye area & & $\vee$ & & V \\
\hline Fat colour & V & & & V \\
\hline Via saleyard & V & & & \\
\hline Cut ageing & V & & & \\
\hline Cooking method & V & & & \\
\hline Individual cut & V & & & \\
\hline
\end{tabular}


cattle for slaughter within Australia prior to export of the beef $[7,18,19]$.

Production systems in southern Australia utilize native and more productive improved temperate pastures and forages and, increasingly, tropical pasture species in regions with more rainfall in the warmer months, such as northern New South Wales $[7,18]$. These systems may be set-stocked or use rotational-type grazing, and irrigation is limited within beef production systems. More marginal beef producing land is utilized more for breeding herds, and better quality pasture is generally provided to growing and/or finishing cattle. Cows are generally bred for a defined period (typically 6 to 12 weeks) to calve in autumn (more southern regions of southern Australia) or spring (more northern regions of southern Australia) depending on the seasonal rainfall and feed availability patterns. British breeds, most notably Angus and Hereford, have been predominant in southern Australia. Large-framed European breeds such as Charolais that are typically used as terminal-sires were introduced in the 1960s [5] for their high yielding qualities, and produce leaner beef for the European Union and the domestic market. The growth of higher-value markets that require marbled beef such as in North Asia has resulted in increased genetic selection pressure for marbling in British breeds, and increasing numbers of Wagyu and Wagyucross cattle. Cattle are typically weaned at 200 to $300 \mathrm{~kg}$ (4 to 9 months of age) and backgrounded on pasture. Yard weaning, which is a low-stress, education process applied during weaning that adapts cattle to handling, facilities and management procedures, may be practiced to help cattle better adapt to later feedlotting. Cattle destined for high-marbling, higher value export markets are feedlot finished. Cattle destined for the domestic market are pasture or short-feedlot (typically 70 days) finished to assure eating quality. Tropically-adapted cattle and their crosses are also increasing in numbers in the more northern regions of southern Australia due to their heat tolerance and yield characteristics. Dairy cattle also represent a significant part meat of the Australian beef industry, with approximately 2.8 million head of dairy cattle in Australia [1]. Dairy or dairy-cross (e.g. Friesian $\times$ Wagyu) cattle for slaughter are an important component of the beef and veal industry in southern Australia.

Northern Australian production systems are generally characterized by lower stocking rates on larger properties than in southern Australia due to geological (soil) and climatic limitations to production $[7,18,19]$. They include savanna- and rangeland-based production systems and vast properties owned by large, more integrated corporate organizations. Improved on-farm infrastructure including cattle handling facilities, improved mustering techniques including use of helicopters, and improved production efficiency in Northern Australia were enhanced by the successful implementation of the BTEC that commenced in 1970 [19]. The BTEC, which required mus- tering and testing of cattle and complete destocking of infected properties resulted in Australia being brucellosis free by 1989 and declared free of tuberculosis in 1997. These developments in the northern Australian beef industry also facilitated a more a rapid shift to tropically-adapted Bos indicus genotypes, as destocked infected properties previously had a higher proportion of Bos taurus cattle.

Apart from very early imports of Zebu or part Zebu cattle from the Cape of Good Hope and Bengal in the late 18th and early 19th century, the first Bos indicus cattle arrived in 1933 but were not imported in significant numbers until the early 1950s $[5,19,20]$. Brahman, Santa Gertrudis and Droughtmaster are the major breeds in northern Australia. Advantages of Bos indicus cattle in northern Australia include tick resistance and heat tolerance. Productivity and product quality advantages can be achieved by using Bos indicus $\times$ Bos taurus crosses, although may be limited to a minimum $5 / 8$ Bos indicus content to maintain adequate tick resistance and heat tolerance. Cow herds may be bred year-round or for defined periods, and are mustered at low frequency compared to southern Australia, once per year or more frequently if bred year-round. The highly seasonal rainfall pattern has generally extended the period from birth to marketing for slaughter beyond the one to two years more typical in southern Australia. There are major economic benefits in reducing the number of dry seasons through which cattle destined for market are maintained. Options to achieve this goal and to provide operational flexibility depending on prevailing seasonal conditions include: sale of younger "store cattle" to specialized backgrounding or feedlot operations; the use of better adapted, more productive pasture and forage species with longer growing seasons; better adapted, more productive cattle genotypes including Bos indicus cross-breeds where suitable; early weaning to enable calves to maintain growth rates on forage and to allow cows to recover body condition and re-breed; use of hormonal growth promotants that provide substantial growth advantages but may impact on product quality (reduce MSA grade), and prohibits access to specific markets (e.g. certain Australian domestic retail outlets and the European Union); and strategic nutritional supplementation particularly of phosphorus and nitrogen to enable better utilization of available forage that may be of low quality $[5,19]$. Geographic isolation, lack of infrastructure including transport, water for stock and irrigation, internal fencing within properties, and slaughter facilities, plus availability and cost of skilled labour are among current limitations to further development of the northern beef industry in Australia [5,19].

Supplementation of cattle with forage and concentrate feeds within Australian pastoral and rangeland systems is essential to maintain productivity as pasture and forage availability and nutritional quality decline due to Australiass variable climate that includes highly seasonal rainfall patterns and severe 
droughts [18,19,21]. Supplements may include for example, grains, molasses and silage for energy, cottonseed, lupins, silage and, in northern Australia, leucaena for protein, and hay and silage for fibre. Various by-products are also fed to cattle, as are protein and mineral lick blocks that may include molasses, urea, a protein meal, salt and/or specific minerals such as calcium and phosphorus $[7,18]$.

Feedlot finishing has assumed more importance in recent years to assure the eating quality of beef entering the domestic market and to enhance the supply of marbled beef for higher value export markets including Japan and Korea. Feedlot cattle undergo an induction program that includes vaccinations and are gradually adapted to the feedlot diet. Feedlot diets vary according to the length of time cattle spend in the feedlot. Feedlot diets are specifically formulated to provide high energy to cattle and include grains such as wheat, barley and sorghum, sources of fibre such as hay or silage, a protein source such as sunflower or lupins, and water, vitamins and minerals [22]. Leucaena may also be used as a forage supplement in northern systems. A total of 2.7 million grain fed cattle were marketed in 201617 representing about $35 \%$ of all adult cattle slaughtered in Australia in 2016-17 [1].

Genetic improvement: The national program for genetic improvement of beef cattle in Australia is BREEDPLAN [2]. BREEDPLAN offers beef cattle breeders the potential to accelerate genetic progress in their herds and to provide objective information on stock they sell. The phenotypes collected as a part of BREEDPLAN include live weight and growth, carcass, fertility, birth, efficiency, temperament and soundness traits (Table 2). New Zealand, Namibia, Thailand and the Philippines also use BREEDPLAN as their national beef recording schemes, and BREEDPLAN is also used in various other countries including the USA, Canada, United Kingdom, South Africa, Hungary and Argentina [3].

BREEDPLAN uses an advanced, modern genetic evaluation system based on Best Linear Unbiased Prediction technology incorporating multi-trait analysis procedures to produce estimates of breeding values (EBVs or EPDs) [2,3]. Pedigree and performance information of individuals, performance of known relatives and any progeny, known relationships between traits, and any genomic information on the animal are used in determining EBVs. Among a range of companion products

Table 2. Phenotypic traits with Estimated Breeding Values currently within BREEDPLAN, the Australian genetic evaluation system for beef cattle [2]

\begin{tabular}{|c|c|c|c|}
\hline Live weight & Fertility/calving & Carcass & Other \\
\hline Birth & Scrotal size & Carcass weight & Docility \\
\hline Milk & Days to calving & Eye muscle area & Net feed intake \\
\hline 200 day & Gestation length & Fat depth & Structural Soundness \\
\hline 400 day & Calving ease & Retail beef yield & Flight time \\
\hline 600 day & & Intramuscular fat \% & \\
\hline Mature cow & & Shear force & \\
\hline
\end{tabular}

in BREEDPLAN is BreedObject, which calculates selection indices to rank cattle based on their overall genetic merit for a specific breeding objective. BreedObject uses weightings of EBVs for individual traits, based on the contribution each trait makes to the profitability of an enterprise given the specifics of the production system and the target market.

Stud herds that use BREEDPLAN aim to provide improved genetics for Australian commercial beef producing herds. In 2015, there were 135,689 registered beef cattle in Australia, including 32 breed societies with 100 or more registered cattle [2]. Of these, $58.0 \%$ of cattle were British breed, $20.7 \%$ tropical breed, 14.7\% European breed and 6.6\% other breed types. The 10 breeds with highest representation were Angus (33.0\% of registered beef cattle), Brahman (13.4\%), Hereford (11.7\%), Santa Gertrudis (7.5\%), Droughtmaster (6.0\%), Wagyu (4.3\%), Charolais (4.1\%), Limousin (3.3\%), Shorthorn (3.1\%), and Simmental (2.8\%). The number of registered cattle in Australia has been relatively stable over the past two decades.

\section{Markets and market prospects for Australian beef and cattle}

Historical and current market situation: In 2016-17, Australia produced approximately 2.07 million tonnes (carcass weight) of beef and veal for export and domestic consumption [1]. Australians consumed about $26 \mathrm{~kg}$ of beef per head and spent $\$$ A8.5 billion on beef in 2016-17. Beef had the highest value of retail sales per capita of any meat in Australia, and was third on a volume per capita basis behind chicken and seafood. However, Australiass relatively small domestic population (24.5 million) and total domestic beef consumption relative to total beef production enables large quantities of beef to be exported $[1,4]$.

The Australian beef export industry has been characterized by four major eras ([23], Figure 5): British era prior to 1973; US era from 1973 to 1987 which saw major expansion of Australian beef exports, primarily for manufacturing beef; the North Asian era in which beef exports increased to include higher value product to Japan and Korea from 1987 to 2009, underpinned by trade negotiations and liberalization in these countries; and the Developing Asia era since 2009, with rapid export growth to China and Indonesia in particular. Major events that have affected Australian beef exports within these periods are also shown in Figure 6. The resilience and growth of the of the Australian beef export industry is underpinned by the maintenance and/or growth and development of existing markets such as the US and in North Asia while diversifying into a wide range of export markets globally.

Australia has built a strong reputation globally as a supplier of assured, high quality beef and cattle due to its capacity to meet stringent market specifications, livestock health and food safety requirements, as described in the section on Biosecurity and Quality Assurance above. 


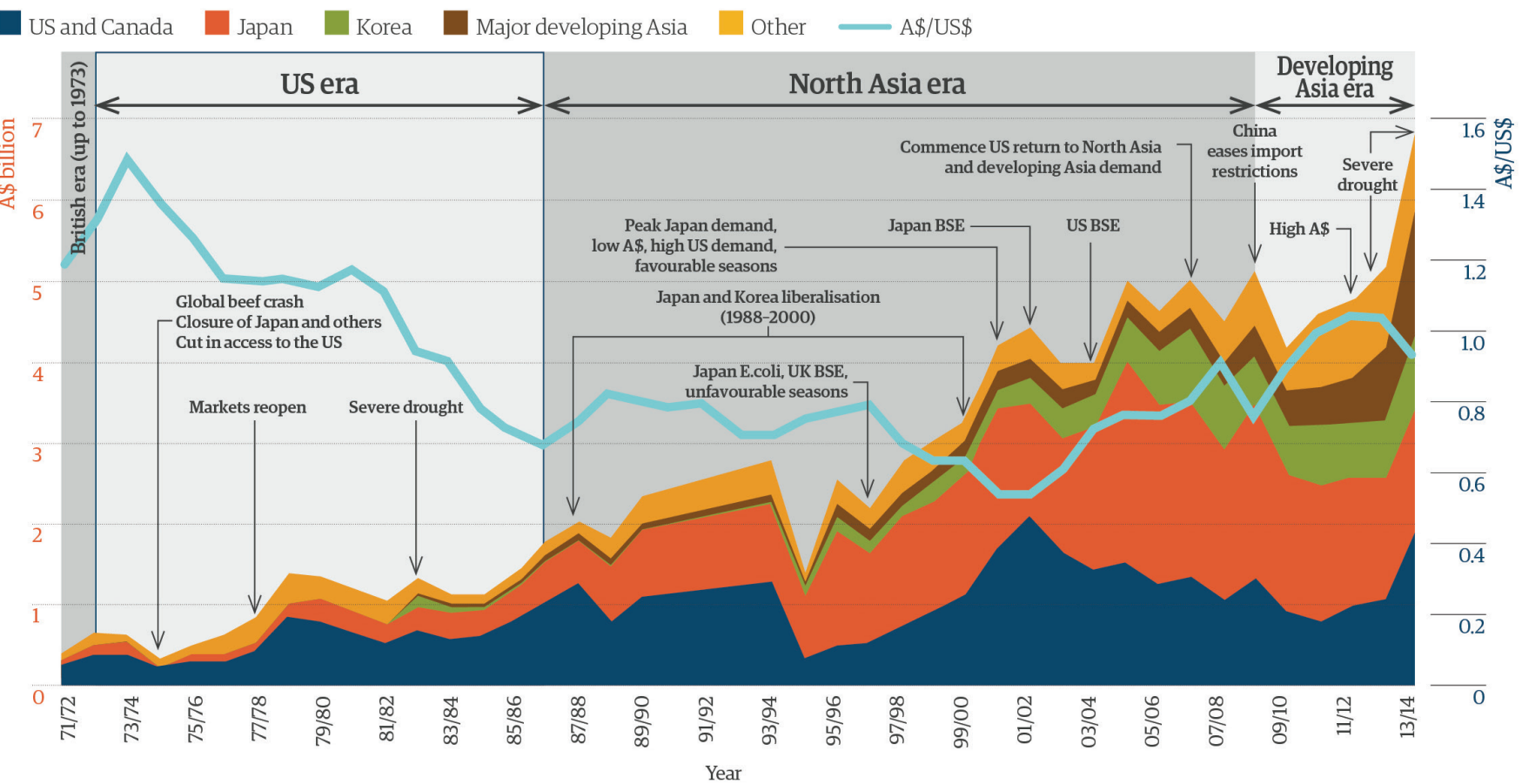

Figure 5. Australian beef export values, Australian-US exchange rate and significant market developments [23].

Australia was the world's third largest beef exporter in 2016, after India and Brazil (Figure 1). Australia exported $68 \%$ of its total beef and veal production in 2016-17, to a total of 77 countries [1,4]. The value of Australian beef and veal exports in 2016-17 was $\$$ A7.1 billion [1]. The major markets for Australian beef are Japan, (29\% of Australian beef exports in 2016$17)$, USA (22\%), Korea (17\%), China (10\%), Indonesia (5.3\%), and Taiwan (3.2\%).

Australia also exported 907,965 head of live cattle worth \$A1.2 billion in 2016-17 [1]. Indonesia (59\% of Australian cattle exported in 2016-17), Vietnam (18\%), China (8.2\%), Israel (4.8\%), Turkey (4.5\%), and Malaysia (2.3\%) were the major markets for Australian cattle.

Market prospects: Longer-term market prospects for Australian beef appear to be positive due to strong potential for continued export market growth, particularly into higher value and emerging Asian markets where consumer wealth and demand for high quality protein are increasing. However, factors including export competition from South American countries, USA and India for example, will likely influence Australia’s market penetration into certain emerging and existing Asian markets [4,6]. Maintenance of Australia’s preferred status as a quality assured supplier of high value beef produced under environmentally sustainable systems from 'diseasefree' cattle is of high importance and is crucial for continued growth of export markets. However, improvements in health status of cattle and traceability of beef by South American beef exporting nations, coupled with their lower production costs, have been reducing the gap between these countries and Aus- tralia as a preferred beef supplier. Continued efforts to maintain advantages in provenance coupled with productivity growth across the supply chain to ensure price competiveness will be important for continued export market growth for Australian beef in the face of increasing competition [6]. Indonesia's efforts towards self-sufficiency in beef production and alternative sources of beef may impact on future livestock exports from northern Australia [19].

\section{CHALLENGES AND OPPORTUNITIES FOR THE AUSTRALIAN BEEF INDUSTRY}

\section{Global megatrends}

A number of so-called megatrends that will influence agricultural industries including the Australian beef industry were identified by Hajkowicz and Eady [24] using a strategic foresight process. Megatrends are defined as a more important trajectory of change expressing itself over a decadal period, with far-reaching implications for the organisation occurring at the intersection of multiple trends. The important agricultural megatrends identified by Hajkowicz and Eady [24] (Figure 6) were:

- A hungrier world: Population growth will drive global demand for food and fibre;

- A wealthier world: A growing middle class will increase food consumption, diversify diets and eat more protein;

- Choosy customers: Information empowered consumers of the future will have expectations for health, provenance, sustainability and ethics; 


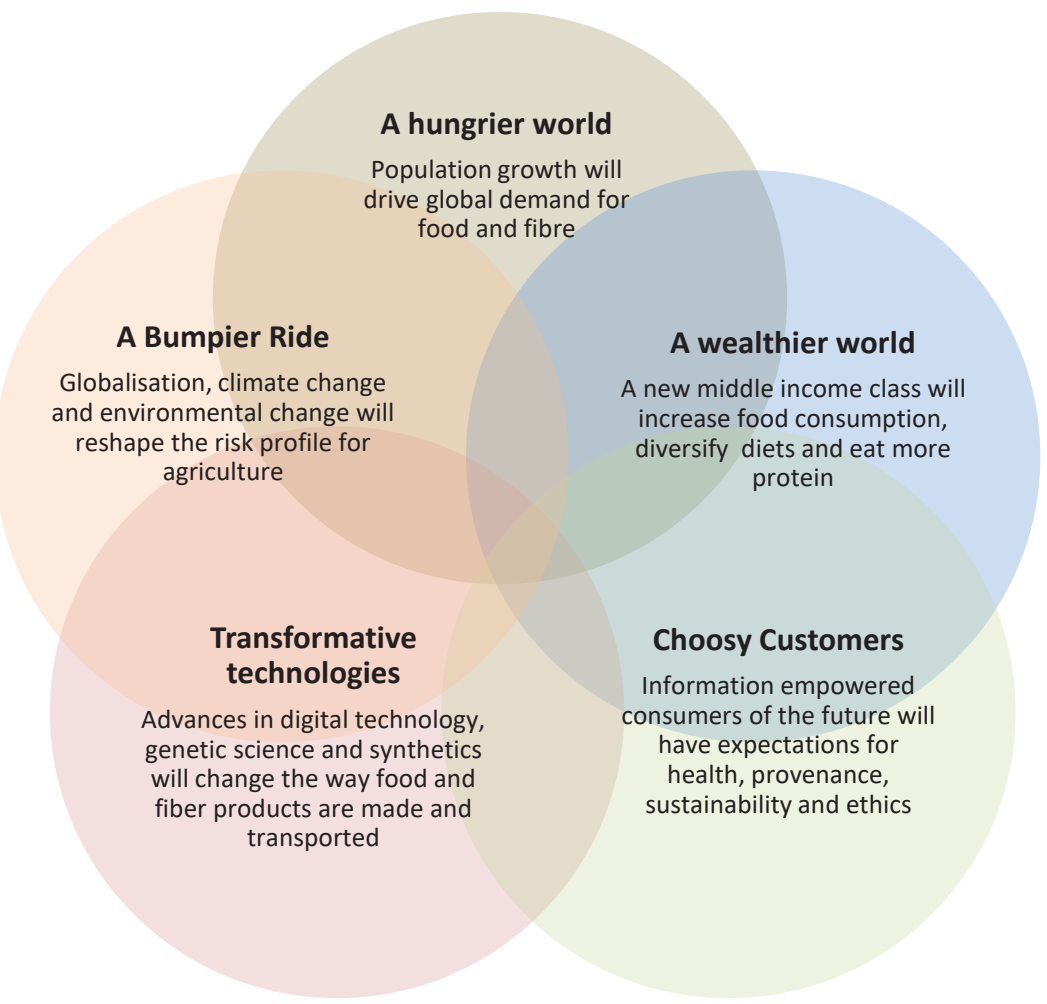

Figure 6. Agricultural megatrends likely to impact on the Australian and global beef industries [24].

- Transformative technologies: Advances in digital technology, genetic science and synthetics will change the way food and fibre products are made and transported;

- A bumpier ride: Globalisation, climate change and other impacts on the environment including human activities will reshape the risk profile for agriculture;

In the context of the beef sector there are some specific points to highlight. Firstly, it is unlikely that the future global food demand will be serviced by traditional animal and plant sources, even after significant gains in production efficiencies. Production of human food derived from non-animal/plant sources such as insects or manufactured synthetically will inevitably increase. For beef, the competition from other animal and non-animal protein sources will remain a challenge but the increasing affluence in developing countries (i.e. a "wealthier world") will offset some competitive pressure.

Secondly, the beef industry responses to address these global trends must be actioned in an integrated manner. Ruminants can uniquely utilize rangeland, not suitable for cropping, to produce food and fibre for humans, however, there is a clear imperative to increase production efficiency. This will require an integrated approach that focuses on identifying and selecting animals that can maintain higher productivity from less resource and optimizing the management and production system of these animals to ensure their genetic potential is realized. Harnessing the power of genomic, nutritional and digital animal management technologies will be paramount in order to achieve step-change gains in production efficiency. However, any gains in production efficiency must be achieved ethically and sustainably in order to satisfy more discerning markets and consumers (i.e. "choosy customers"). The role of ruminants in the production of greenhouse gases is well documented but recent research has demonstrated there are multiple strategies that can simultaneously improve animal productivity whilst reducing methane emissions in cattle [25].

Quite recently, the Australian beef industry has taken on the aspirational goal to be carbon neutral by 2030 [26]. This will be quite challenging to achieve given that it will require a simultaneous attack on mitigating carbon loss (through methane emissions) and increasing carbon capture in beef production systems. However, it will be central to the dual aim of demonstrating the sustainability of the sector and maximizing the trust and confidence in Australian beef products.

In this context, as a component in assessing quality of foods from livestock, an environmental index that takes into account carbon footprint, water and energy use has also been proposed [27]. These authors identified priorities for livestock production including whole of life cycle analyses in the area of environmental mitigation, and selection for profitable animals under different production systems as part of adaptation strategies. They also identified the need for a fundamental shift in the design of production systems to help ensure present and 
future needs for animal products are met without compromising future generations [27].

Priorities and strategies to enhance the future for the Australian beef industry

Strategic planning: In response to factors affecting the future of the Australian beef industry including global megatrends, major issues that represent research, development and adoption (RD\&A) priorities and opportunities for the Australian beef industry have been captured within exhaustive strategic planning processes for the red meat [28] and beef [29] industries, including the southern [30] and northern [31] beef industries in Australia (Figure 7). These priorities which are detailed in Figure 8 guide funding by Australian Rural Development Corporations for RD\&A activities undertaken by Australian Federal and State Agencies, Universities and industry. The pillars and priorities within these plans include consumer and industry support, product and systems integ-

Meat Industry Strategic Plan 2020 Pillars and Priorities

Consumer and community support

- Welfare of animals

- Stewardship of environmental resources

- Red meat in a healthy diet

Market growth and diversification

- Efficiency and value in trade and market access

- Marketing and promoting Australian red meat and livestock

Supply chain efficiency

- Optimising product quality and cost efficiency

- Guaranteeing product and systems integrity

\section{Productivity and profitability}

- Production efficiency in farms and feedlots

- Processing productivity Live export productivity
Beef Industry Strategic Plan 2020 Priorities for Action

Top priorities

- Market and promote Australian beef

- Welfare of animals

- Optimising product quality and cost efficiency

High priorities

- Guaranteed product and systems integrity

- Production efficiency on farms

- Efficiency and value in trade and market access

\section{Medium priorities}

- Stewardship of environmental resources

- Market and promote Australian beef-domestic markets

- Red meat in a healthy diet

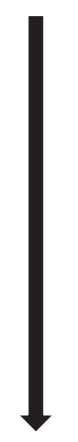

Rural Development Corporation

Strategic and Corporate Plans

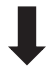

Federal and State Agencies, Universities and Industry: Program and Sub-program Areas rity, market growth and diversification, supply chain efficiency, productivity, efficiency and profitability of beef production systems, health and welfare of cattle, and environmental stewardship. Challenges and opportunities for the Australian beef industry were also discussed by Bell et al [5] and Gleeson et al [19], and in relation to livestock nutrition, by Poppi and McLennan [21], with particular emphasis on Northern Australia where there is potential for substantial expansion of beef production.

Automation and data integration: Application of "transformative technologies" to enhance productivity and efficiency across the beef value chain: We are seeing the development of new, revolutionary capacity to make measurements and to understand and improve agricultural ecosystems and supply chains. This is based on the development of new sensing technologies including wireless sensor networks, and the associated capacity to capture, manage, analyse and develop applications from "big data". These developments will enable measurement
Southern Australia Meat Research Council RD\&A Plan - Consolidated Priorities

A Farm systems approach

Feed base development

- Enhanced feed base

- Grow and use more feed

- Filling the late Autumn feed gap

- Better use of supplementary feeding and novel feed sources

- Better use of perennials and

summer actives

- Water use efficiency

- Grazing management in the rangelands

- Total species integration and

management

- Pastures in mixed cropping systems

Supply chains

- Increased objective carcase measurement and feedback

- Certification, branding, benchmarking, transparency

- Improved use of technology

- Consistency of supply

- Consumer issues

- Supply chain development

Extension - better adaption of knowledge

Animal productivity, health and welfare

- Animal-Feed base interactions

- Genetic improvement

- Improved animal welfare practices

- Increased weaning rate and reproduction,

reduced mortality

- Use of new technology

- Managing disease and parasites

- On-farm biosecurity

- Providing credentials

- Response to parasite resistance
North Australia Beef Research Council RD\&A Plan - Consolidated Priorities

Reproduction

- Rapid dissemination of superior genetics

- Reduce losses from pregnancy test to weaning

- Develop producer's pathway to efficiency

Grazing land management

- Enhanced grazing management

- Weeds and feral animals

- Great producer decisions

- Cattle, carbon, and catchments

Nutrition and growth

- Optimise production from the pasture base (or Feed base)

- Efficiency-at-pasture phenotypes

- Improved supplementation

- Accelerate growth pathways for lifetime productivity

- Optimised rumen function

Human capacity and enabling change

- Facilitating continuous improvement of RD\&E, education and training

- Ensuring continuity of supply of skilled people

- Understanding emerging people and socia issues

- Regenerating RD\&E culture and learning

Animal welfare

- Improved husbandry practices

Continuous improvement in beef cattle welfare

- Closing the gap between perception and reality for beef cattle welfare

Information technology and precision livestock management

- Finer scale management of animals, pastures and landscape

- Agricultural services

- Technologies

Figure 7. National research, development and adoption (RD\&A) priorities to enhance long-term growth, viability and sustainability of the Australian beef industry [32] 


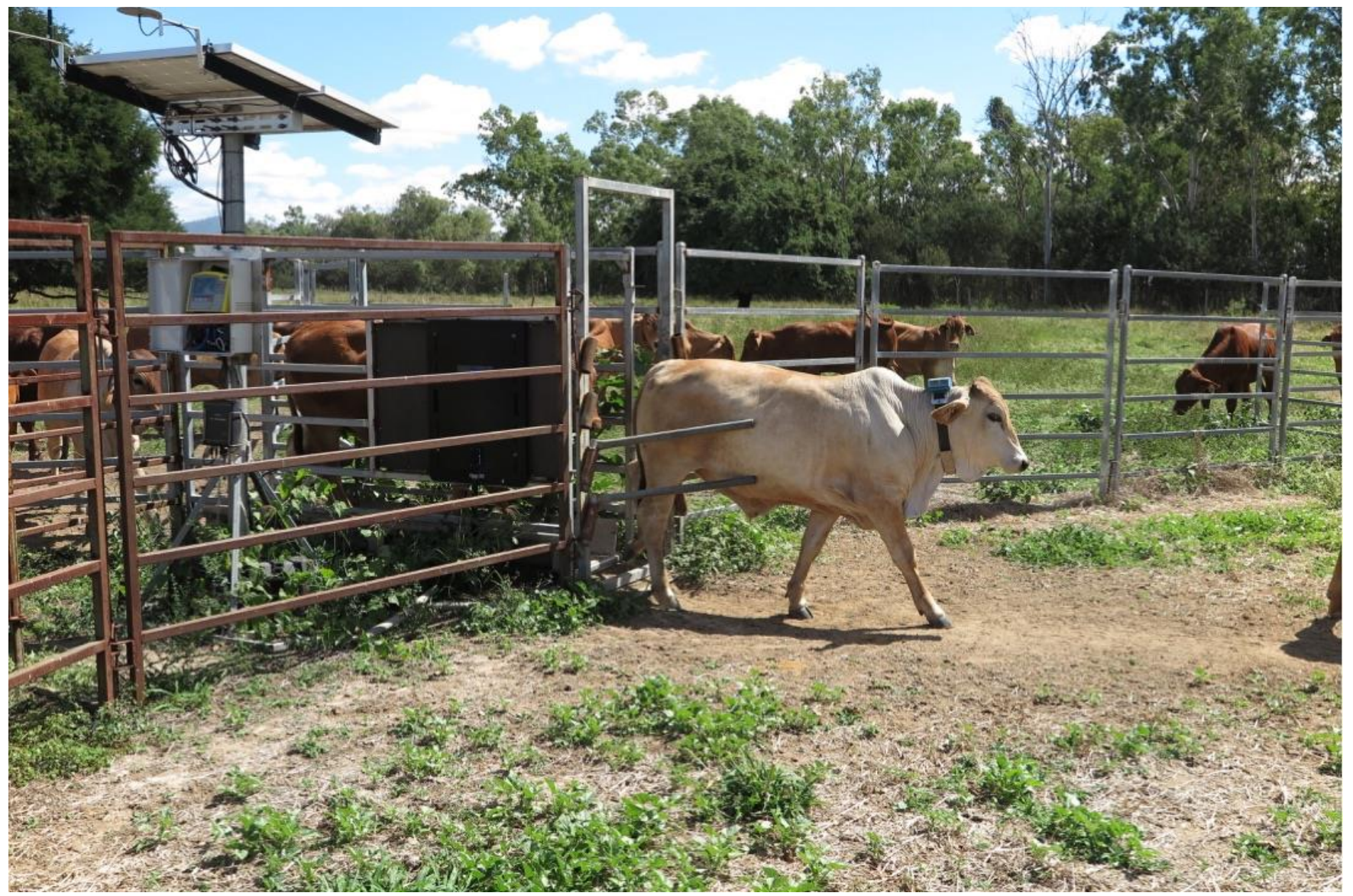

Figure 8. In-field walk-over-weighing combined with on-animal and environmental sensors provide the opportunity to develop automated phenotyping in the commercial grazing environment, and decision support tools and apps to enhance productivity, efficiency and sustainability of beef production systems (Photograph: Dr Greg BishopHurley, CSIRO, Australia).

and application of traits not previously possible or conceivable. They will enable the development of automated phenotyping, or livestock phenomics, which will underpin advances in genetic improvement through genomics and in precision pasture, livestock and supply chain management. Real-time, sensor platform technologies, e-management systems and predictive biological traits are being developed and incorporated into these labour saving, automated data collection and management systems [33]. These systems will evolve to evaluate key efficiency constraints within commercial pasture-based systems including intake and feed efficiency at pasture, behaviour, disease susceptibility, health, reproduction and welfare status. Once linked with carcass data and market signals from further along the supply chain, this will allow the development of applications that improve whole farm profitability, riskmanagement and compliance to market specifications. They will also enable interactions with the environment to be monitored and better understood.

The next generation of phenotyping of traits measured on individual animals, methodologies to acquire them, and increased computational capacity required to analyse data is known as Phenomics. Animal phenomics has been defined as the acquisition of high-dimensional phenotypic data on an animal-wide scale [34]. We have extended this definition to include the real-time acquisition of high density behavioural and physiological input and response measures coupled with data describing the production environment [33].

Emerging livestock phenomics methodologies include: i) sensory-based approaches to develop traits diagnostic of productivity, efficiency and product quality, as well as animal resilience, health and welfare; and ii) automated on-farm and across supply chain methods for data collection that drive management solutions to reduce input costs, accelerate genetic gain, to enhance production and processing efficiency. There are numerous technological and analytical challenges associated with the use of these technologies to achieve the objective of establishing a livestock phenomics platform, as reviewed by Greenwood et al [33].

The capacity to understand factors that underpin productivity and efficiency in pastoral ecosystems is limited by our ability to measure intake and efficiency of utilization of feed and environmental factors that contribute to variation in efficiency within commercial grazing environments. Initial traits being targeting in development of a livestock phenomics plat- 
form for efficiency at pasture are voluntary intake of pasture by individual grazing animals and liveweight $[33,35,36]$ (Figure 8), and also include reproductive success for the breeding herd. Pasture intake is the key input trait that underpins livestock production efficiency, and this plus automated methods for frequent reliable measurement of liveweight and liveweight change over time are being established $[33,35,36]$. A schematic for a more comprehensive livestock phenomics platform for efficiency at pasture is presented in Figure 9.

A key constraint to the precision of these systems is the use of liveweight as the sole indicator of growth performance. There can be considerable variation in carcass lean meat between animals of similar weight, leading to decelerated genetic gain for rapid growth of meat in the carcass. Although ultrasound can be used to determine back fat depth, single point measures have been shown to be relatively imprecise and inaccurate for determining the lean composition of carcasses [37]. There are a number of technologies that show promise for determining carcass composition in live animals which would address this reduced precision. These include Dual Energy X-ray absorptiometry [38], and 3-dimensional imaging technologies being developed as part of the Advanced Livestock Measurement Technologies project within Australia.

Although there is a focus on developing generic approaches to livestock phenomics of grazing cattle, it is important to acknowledge that the number of variables that can be measured renders it impossible to develop a single approach that will perform across all applications. However, it is possible to develop a streamlined workflow that can be used in most situations which provide guidance to facilitate successful outcomes in the generation of new traits. A workflow system being used for sensor based assessment of behaviours associated with development of algorithms to estimate intake of pasture by individual grazing livestock is detailed by Greenwood et al [33]. Utilisation and delivery of automated, remote data collection from multiple sources from livestock and the environment will also be supported by the development of electronic interfaces such as "apps" and "dashboards" [33].

An additional opportunity to enhance industry profitability, efficiency and capacity to meet market specifications is the development of objective methods to allow market signals and product value to be translated down the supply chain to producers of beef. This requires the use of automated, objective measurement technologies to enhance the capacity of producers and processors to meet market specifications more reliably, and to increase producer profitability. This is summarised for the beef value chain in Figure 10. Thus, linking measurements that accurately capture commercial cut weights

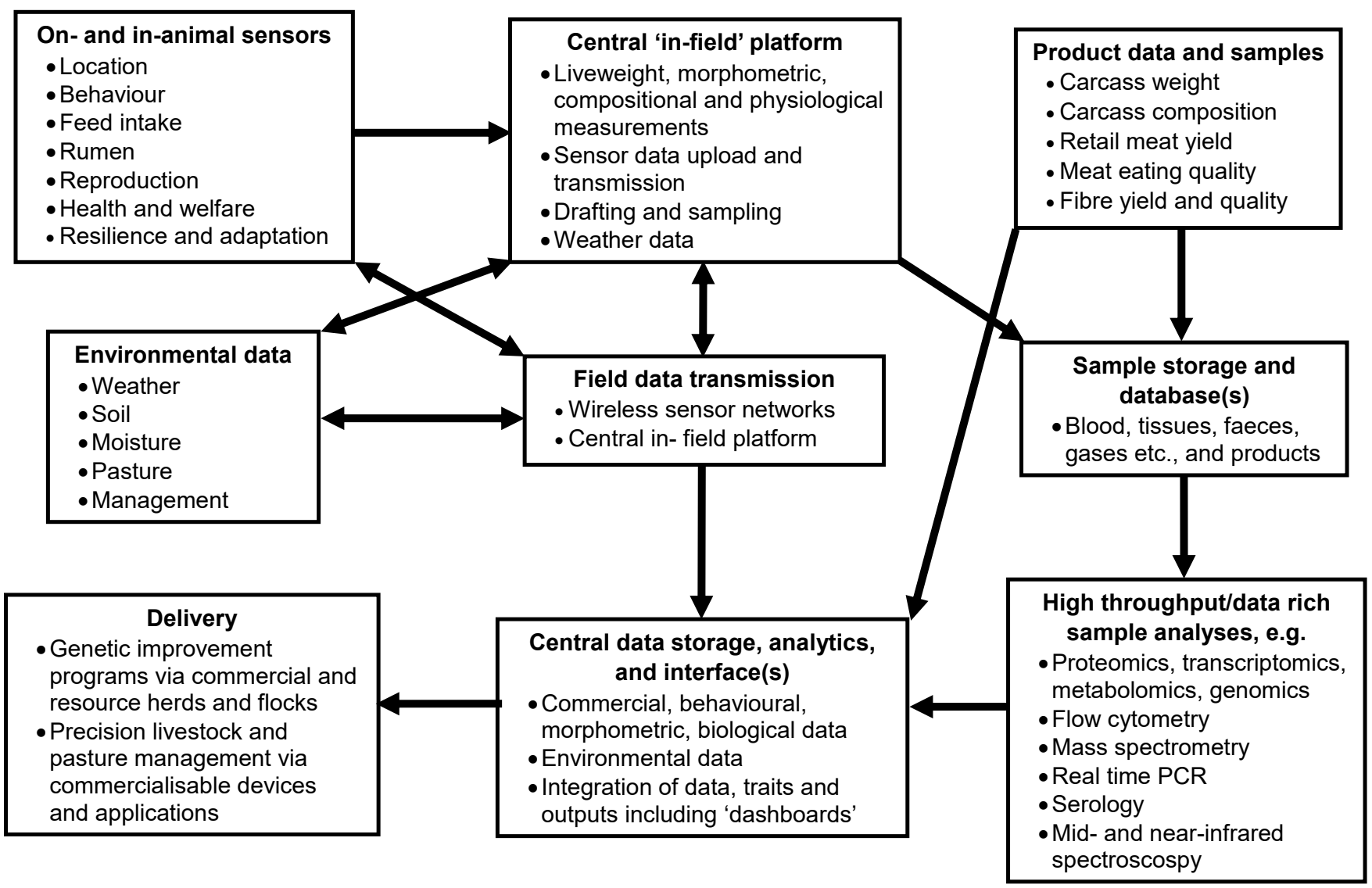

Figure 9. Schematic representation of efficiency at pasture phenotyping network for grazing livestock meat (and fibre) production [33]. Also see Figures 8 and 10. 


\section{Precision Measurement from paddock to plate: VALUE CHAIN Predict quality and amount of final product}

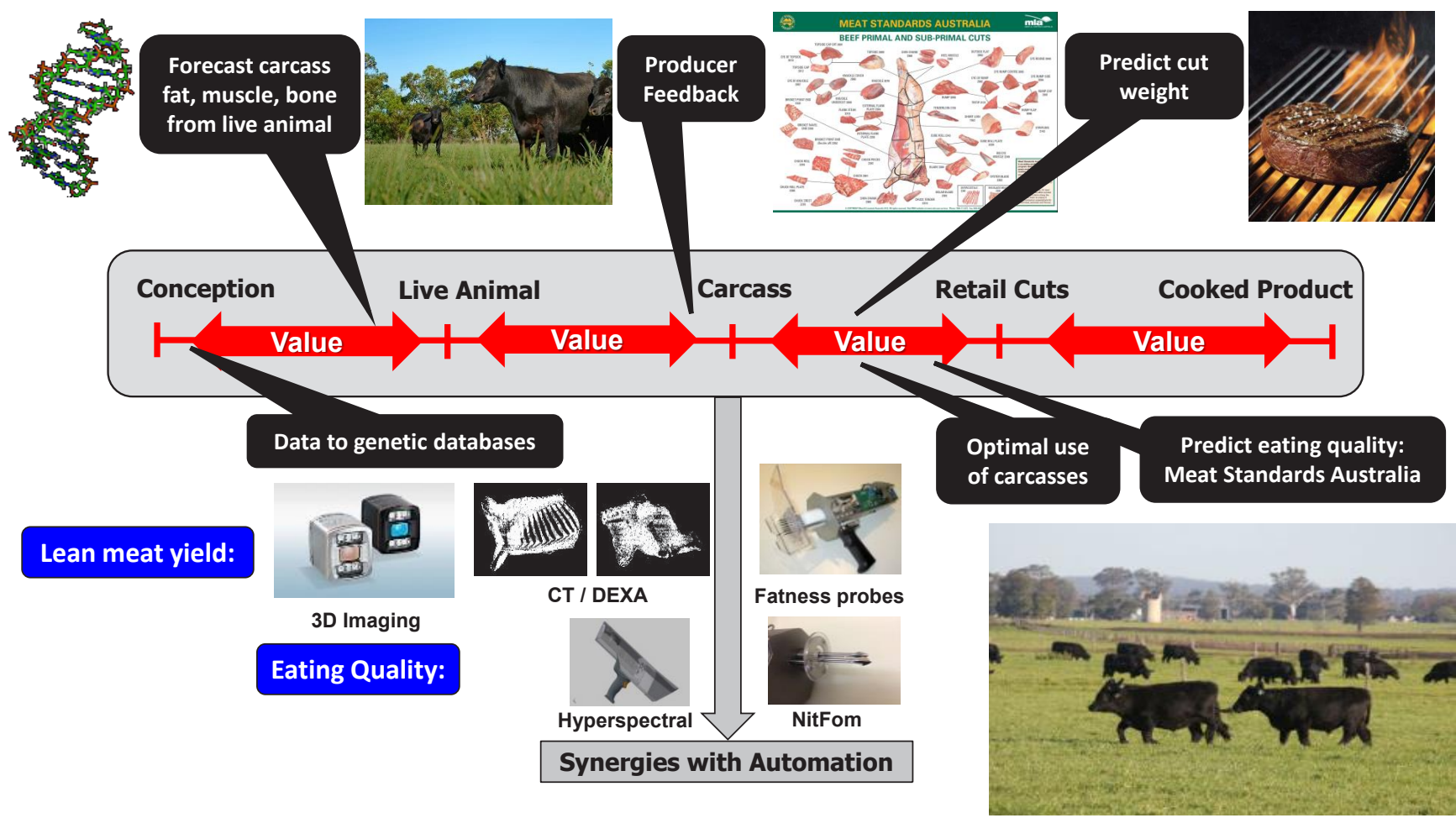

Figure 10. Objective measurement technologies and data links across the Australian beef value chain will enable feedback from the market and better management decisions to improve production and processing efficiencies and compliance with market specifications.

as well as their eating quality will enable more targeted delivery of beef products to markets. This will improve market confidence, particularly where high quality products are demanded, underpinning higher prices and greater value generation. In turn, these measurements will enable price signals to producers that more accurately reflect the quality and quantity of beef sold, facilitating a more responsive production sector.

\section{CONCLUSION}

Market prospects for Australian beef remain strong due to existing domestic and export markets, and emerging export markets particularly in Asia. Profitability of the Australian beef industry will continue to depend on market stability and growth, and on the capacity of beef producers to more efficiently meet market specifications. Maintenance and improvements in Australia's reputation as a preferred, reliable supplier of 'disease-free' product that meets market specifications remains essential for market access, and improvements in objective measurement and price signaling of beef quality, carcass, and production and efficiency traits to producers will enhance their capacity to increase productivity and improve profitability. Long-term improvements in productivity, efficiency and sustainability of production systems will underpin continued market growth and development of the Australian beef industry.

\section{CONFLICT OF INTEREST}

We certify that there is no conflict of interest with any financial organization regarding the material discussed in the manuscript.

\section{ACKNOWLEDGMENTS}

The authors acknowledge the contributions of Dr Ed Charmley (CSIRO) and Steve Exton (NSW Department of Primary Industries) who provided valuable feedback to improve this paper. 


\section{REFERENCES}

1. MLA. Fast Facts [Internet]. Sydney, NSW, Australia: Meat and Livestock Australia; 2017 [cited 2018 March 25]. Available from: https://www.mla.com.au/.../mla.../fast-facts.../mla_beeffast-facts-2017_final.pdf

2. ABRI. BREEDPLAN A modern genetic evaluation system for beef cattle [Internet]. Agricultural Business Research Institute; 2017 [cited 2018 Mar 25]. Available from: http://breedplan. une.edu.au/brochures/BREEDPLAN\%20Flyer\%20Web.pdf

3. ABRI. BREEDPLAN International [Internet]. Agricultural Business Research Institute; 2017 [cited 2018 Mar 25]. Available from: http://breedplan.une.edu.au/brochures/International\%20 Brochure\%20A4.pdf

4. MLA. Global Market Snapshot Beef [Internet]. Sydney, NSW, Australia: Meat and Livestock Australia; 2017 [cited 2018 Mar 25]. Available from: https://www.mla.com.au/globalassets/ mla-corporate/prices--markets/documents/os-markets/redmeat-market-snapshots/mla-global-snapshot-beef-2017.pdf

5. Bell AW, Charmley E, Hunter RA, Archer JA. The Australasian beef industries - Challenges and opportunities in the 21st century. Anim Front 2011;1:10-9.

6. Hyde M, Thorpe S, Waring A, Moir B, Gunning-Trant C. South America: An emerging competitor for Australia's beef industry. Canberra, ACT, Australia: Australian Bureau of Agriculture and Resource Economics; 2017. ABARES Research Report 2016:16.14.

7. Pricewaterhouse Coopers. The Australian beef industry. The basics [Internet]. Pricewaterhouse Coopers; 2011 [cited 2018 Mar 25]. Available from: https://www.pwc.com.au/industry/ agribusiness/assets/australian-beef-industry-nov11.pdf

8. ABM. Climate classification of Australia [Internet]. Australian Bureau of Meteorology; 2005 [cited 2017 Mar 25]. Available from: http://www.bom.gov.au/jsp/ncc/climate_averages/climateclassifications/index.jsp?maptype=kpngrp\#maps

9. Ding MJ, Jie F, Parton KA, Matanda MJ. Relationships between quality of information sharing and supply chain food quality in the Australian beef processing industry. Int J Logist Manag 2014;25:85-108.

10. AHA. Disease information [Internet]. Animal Health Australia; 2017 [cited 2018 March 25]. Available from: https://www. animalhealthaustralia.com.au/disease-information/

11. More SJ, Radunz B, Glanville RJ. Lessons learned during the successful eradication of bovine tuberculosis from Australia. Vet Rec 2015;177:224-32.

12. Department of Agriculture. Eradication success story-Australia is free of Brucella abortus [Internet]. Department of Agriculture; c2017 [cited 2018 March 25]. Available from: www. agriculture.gov.au/SiteCollectionDocuments/.../brucellaabortus-colour.docx

13. NLIS. Welcome to NLIS. Australia’s National Livestock Identification System [Internet]. National Livestock Identification
System; 2017 [cited 2018 Mar 25]. Available from: https://www. nlis.com.au/

14.DAWR. Exporting meat and meat products [Internet]. Department of Agriculture and Water Resources; 2017 [cited 2018 Mar 25]. Available from: http://www.agriculture.gov.au/export/ controlled-goods/meat

15.AUS-MEAT. AUS-MEAT [Internet]. AUS-MEAT Limited; 2017 [cited 2018 Mar 25]. Available from: https://www.ausmeat. com.au/home.aspx

16. MSA. Meat Standards Australia beef [Internet]. Meat and Livestock Australia; 2014 [cited 2018 March 25]. Available from: http://www.mla.com.au/globalassets/mla-corporate/ marketing-beef-and-lamb/msa-beef-brochure_aus_lowres. pdf

17. MSA. Meat Standards Australia beef information kit [Internet]. Meat and Livestock Australia; 2017 [cited 2018 Mar 25]. Available from: https://www.mla.com.au/globalassets/mlacorporate/marketing-beef-and-lamb/documents/meatstandards-australia/tt_msa-beef-info-kit_low-res.pdf

18. AgriFutures Australia. Beef cattle [Internet]. AgriFutures Australia; 2017 [cited 2018 Mar 25]. Available from: http://www. agrifutures.com.au/farm-diversity/beef-cattle/

19. Gleeson T, Martin P, Mifsud C. Northern Australian beef industry. Assessment of risks and opportunities. Canberra, ACT, Australia: Australian Bureau of Agricultural and Resource Economics and Sciences; 2012. ABARES report to client prepared for the Northern Australia Ministerial Forum.

20.Parsonson IM. The Australian ark: A history of domesticated animals in Australia. Collingwood, VIC, Australia: CSIRO Publishing; 1998.

21.Poppi DP, McLennan SR. Nutritional research to meet future challenges. Anim Prod Sci 2010;50:329-38.

22.ALFA. About the Australian feedlot industry [Internet]. Australian Lot Feeders Association; 2018 [cited 2018 Mar 25]. Available from: http://www.feedlots.com.au/industry/feedlotindustry/about

23. Weeks P. The beef export revolution [Internet]. Meat and Livestock Australia Feedback: Your Levies at Work May-June pages 6-7; 2015 [cited 2018 March 25]. Available from: https:// www.mla.com.au/globalassets/mla-corporate/news-andevents/documents/publications/feedback_mayjun15_web.pdf

24. Hajkowicz S, Eady S. Rural Industry Futures: Megatrends impacting Australian agriculture over the coming twenty years. Barton, ACT, Australia: Rural Industries Research and Development Corporation; 2015: Publication No. 15/065. Project No. PRJ-009712.

25. MLA. National Livestock Methane Program [Internet]. Sydney, NSW, Australia: Meat and Livestock Australia; 2017 [cited 2018 March 25]. Available from: https://www.mla.com.au/ research-and-development/Environment-sustainability/ national-livestock-methane-program/

26. MLA. Red meat industry can be carbon neutral by 2030 [Inter- 
net]. Meat and Livestock Australia; 2017 [cited 2018 Mar 25]. Available from: https:/www.mla.com.au/news-and-events/ industry-news/red-meat-industry-can-be-carbon-neutralby-2030/

27.Scollan ND, Greenwood PL, Newbold CJ, et al. Future research priorities for animal production in a changing world. Anim Prod Sci 2011;51:1-5.

28. RMAC. Meat Industry Strategic Plan. MISP 2020 including outlook to 2030 [Internet]. Red Meat Advisory Council; 2015 [cited 2018 Mar 25]. Available from: http://rmac.com.au/wpcontent/uploads/2016/12/MISP-2020-doc.pdf

29.CCA. Beef Industry Strategic Plan 2020 [Internet]. Cattle Council of Australia; 2015 [cited 2018 Mar 25]. Available from: http://e-doc.me/cattlecouncil1/cattlecouncil1/assets/ common/downloads/publication.pdf

30.SAMRC. Southern Australia Meat Research Council. Research, Development \& Adoption Plan 2016 [Internet]. SAMRC Incorporated; 2016 [cited 2018 Mar 25]. Available from: http:// www.samrc.com.au/wp-content/uploads/2016/08/2016SAMRC-Plan-Second-Release.pdf

31.NABRC. Research, Development and Extension (RD\&E) Priorities Prospectus for the Northern Australian Beef Industry [Internet]. North Australia Beef Research Council; 2012 [cited 2018 Mar 25]. Available from: http://www.jackiekyte.com.au/ nabrc/public/files/Prospectus.pdf

32. Exton S. Extensive Livestock Industries Unit Plan 2017-2022.
Wagga Wagga, NSW, Australia: NSW Department of Primary Industries; 2017.

33. Greenwood PL, Bishop-Hurley GJ, Gonzalez LA, Ingham AB. Development and application of a livestock phenomics platform to enhance productivity and efficiency at pasture. Anim Prod Sci 2016;56:1299-311.

34. Houle D, Govindaraju DR, Omholt S. Phenomics: The next challenge. Nat Rev Genet 2010;11:855-66.

35. Greenwood PL, Valencia P, Overs L, Paull DP, Purvis IW. New ways of measuring intake, efficiency and behaviour of grazing livestock. Anim Prod Sci 2014;54:1796-804.

36. Greenwood PL, Paull DR, McNally J, et al. Use of sensor-determined behaviours to develop algorithms for pasture intake by individual grazing cattle. Crop Pasture Sci 2017;68:1091-9.

37. Williams A, Jose CG, McGilchrist P, et al. Predicting beef carcase composition from weight and rib fat depth. In: Proceedings of the International Congress of Meat Science and Technology, 2017: 2017 Aug 13-16: Cork, Ireland. pp. 725-8.

38. Gardner G, Glendenning R, Brumby O, Starling S, Williams A. The development and calibration of a dual X-ray absorptiometer for estimating carcass composition at abattoir chainspeed. In: Proceedings of Fourth Annual Conference on Body and Carcass Evaluation, Meat Quality, Software and Traceability (FAIM IV) 2015; 2015 Sept 22-23, Edinburgh, Scotland, UK: European Cooperation in Science and Technology; 2015 pp. 22-5. 